Article

\title{
Snapshot of Cyprus Raw Goat Milk Bacterial Diversity via $16 S$ rDNA High-Throughput Sequencing; Impact of Cold Storage Conditions
}

\author{
Eleni Kamilari ${ }^{\circledR}$, Dimitrios A. Anagnostopoulos ${ }^{\circledR}$, Photis Papademas $₫$, Marina Efthymiou, \\ Svitlana Tretiak and Dimitrios Tsaltas *(1) \\ Department of Agricultural Sciences, Biotechnology and Food Science, Cyprus University of Technology, \\ Limassol 3036, Cyprus; eleni.kamilari@cut.ac.cy (E.K.); da.anagnostopoulos@edu.cut.ac.cy (D.A.A.); \\ photis.papademas@cut.ac.cy (P.P.); ml.efthymiou@edu.cut.ac.cy (M.E.); svitlana.tretiak@ugent.be (S.T.) \\ * Correspondence: dimitris.tsaltas@cut.ac.cy
}

Received: 23 September 2020; Accepted: 22 October 2020; Published: 24 October 2020

\begin{abstract}
In general, it is a common practice among dairy producers to store the milk in the refrigerator directly after milking, in order to preserve it and prevent the development of spoilage microbes. However, the impact of keeping the milk in the refrigerator overnight on milk microbial diversity has been poorly investigated. This study aimed to provide a snapshot of the bacterial composition of goat milk after direct storage at $-80^{\circ} \mathrm{C}$ and after being kept overnight at $4{ }^{\circ} \mathrm{C}$ and then in storage at $-80^{\circ}$, using high-throughput sequencing (HTS). Goat milk samples from four different farms were analyzed, to reveal that milk bacterial diversity differed between the two different storage conditions. Goat milk directly stored at $-80{ }^{\circ} \mathrm{C}$ was characterized by the presence of the Gram-negative contaminants Pseudomonas and Acinetobacter, in addition to the genera Corynebacterium, Chryseobacterium, Bacteroides and Clostridium. Milk samples that were kept overnight at $4{ }^{\circ} \mathrm{C}$ were characterized by a reduction in their bacterial biodiversity and the predominance of the Gram-negative, aerobic Phyllobacterium. Overall, HTS methodologies provide an in-depth identification and characterization of the goat raw milk microbiome. Further, they offer a better understanding of the contribution of cold storage conditions to milk microbiota formation. This study may assist dairy producers in improving raw milk and raw milk cheeses quality and guaranteeing consumers' safety.
\end{abstract}

Keywords: goat milk; cold storage; high-throughput sequencing; bacterial diversity

\section{Introduction}

Goat farming has both economical as well as nutritional importance in the region of the Mediterranean and the Middle East [1,2]. Especially in Cyprus, goat milk is used for the production of traditional products, such as halloumi cheese [3] and Halitzia [4]. Goat milk constitutes a rich source of minerals and vitamins, in addition to nutrients such as proteins, lipids and essential amino acids [5]. Its composition of nutrients which can be more easily digested and absorbed compared to cow milk makes it a better substitute for individuals suffering allergies or intolerance against cow milk proteins. Furthermore, goat milk contains bioactive peptides, which exert antimicrobial, antihypertensive, antioxidant, opioid, cholesterol-lowering, immunomodulant, anti-inflammatory and mineral-binding activities [6-9].

Usually after milking, the milk is temporarily stored in the refrigerator until transfer to the dairy industries. Raw milk storage conditions may affect the microbial communities' composition. Storage of raw milk and milk products at $4{ }^{\circ} \mathrm{C}$ may lead to the development of psychrotrophic bacteria, that play a crucial role in their spoilage [10]. Most psychrotolerants cannot stand the high temperatures applied 
during pasteurization or sterilization procedures. Still, their extracellular enzymes maintain their integrity and remain active, causing deterioration of the quality and reduction in the shelf life of the product [11]. Furthermore, 16S rRNA genes HTS analysis in Grana-like hard cheeses, produced in northwest Italy, indicated that the existence of contaminants in raw milk affected the core microbiome of the cheese, leading to increased representation of spoilage bacteria [12]. Consequently, these may affect the sensorial characteristics of the raw milk cheese. Therefore, the presence of psychrotolerants and spoilage bacteria constitutes a significant concern to dairy producers.

Culture-dependent methodologies do not suffice to provide identification of the microbial composition of aseptically collected milk samples [13]. Currently, high-throughput sequencing (HTS) methodologies have been used for more in-depth characterization of the microbial consortia present in goat milk [4,14-16]. The amplicon sequencing methodology provides the capability to comprehensively identify the microbiota existing inside a sample with improved sensitivity and detection capacities compared to other non-cultured-based methodologies. Additionally, it provides the advantage to detect microbes present in limited amounts or that exist in a viable but nonculturable (VBNC) state [17,18]. This is achieved by massive generation and sequencing of thousands of selected DNA sequences, for instance, the bacterial 16S rRNA gene [19]. Previous HTS-based studies indicated that the bacterial communities of goat milk were mostly composed of Gram-negative Proteobacteria, including the genera Pseudomonas, Acinetobacter, Stenotrophomonas, Enterobacter and Escherichia, and Gram-positive Firmicutes, including Staphylococcus, Bacillus and lactic acid bacteria, such as Streptococcus, Lactobacillus and Lactococcus [4,14-16].

The identification of the bacterial diversity, as well as the influence of cold storage conditions on the bacterial diversity of fresh raw goat milk, has been poorly investigated. The present study aims to provide a snapshot of the bacterial communities of raw goat milk after milking (storage at $-80{ }^{\circ} \mathrm{C}$ to maintain the existent bacterial diversity) and after overnight storage in the refrigerator, by applying Illumina MiSeq amplicon sequencing. The outcomes of this research expect to provide additional knowledge and safety remarks to milk and milk products producers.

\section{Materials and Methods}

\subsection{Sample Collection}

Raw goat milk samples were collected in July 2019 from four dairy farms, located in different geographic areas of the Republic of Cyprus (Table 1). All samples were collected aseptically from bulk tanks, in which milk was obtained using mechanical means apart from sample G3, which was collected manually. Sample G3 was obtained from an organic goat farm. Regarding the remaining dairy farms, the animals' feeding system is semi-extensive. Before milking, the udder and the nipples were cleaned with sterile wet wipes and $70 \%$ ethanol, respectively, and dried using a sterile gauze. All animals were healthy and no antibiotics were administrated prior to sampling. Two $40 \mathrm{~mL}$ milk samples were placed into $50 \mathrm{~mL}$ tubes, placed in cool-boxes and immediately transported to the laboratory. One of the two tubes was kept at $4{ }^{\circ} \mathrm{C}$ overnight $(\mathrm{O} / \mathrm{N} \sim 16 \mathrm{~h})$ and then stored at $-80{ }^{\circ} \mathrm{C}$, and the other was stored immediately at $-80{ }^{\circ} \mathrm{C}$ until processing. Storage at $-80{ }^{\circ} \mathrm{C}$ was applied to prevent the proliferation of microbes and maintain the bacterial communities the same as in direct transfer and processing to the dairy industry.

Table 1. Information regarding the milk samples used in the present study.

\begin{tabular}{cccccc}
\hline $\begin{array}{c}\text { Sample } \\
\text { Name }\end{array}$ & Area of Production & $\begin{array}{c}\text { Type of } \\
\text { Milk }\end{array}$ & Breed & $\begin{array}{c}\text { Number of } \\
\text { Animals }\end{array}$ & Feeding System \\
\hline G1 & Pareklisia/Limassol & Goat & Macheras & 12 & Semi-extensive farming \\
\hline G2 & Kritou Marotou/Paphos & Goat & Macheras & 30 & Semi-extensive farming \\
\hline G3 & Kampia/Nicosia & Goat & Alpine & 3 & Semi-extensive farming \\
\hline G4 & Anogyra/Limassol & Goat & Damascus & 26 & Semi-extensive farming \\
\hline
\end{tabular}




\subsection{Metagenomic DNA Extraction}

For sample homogenization, $5 \mathrm{~mL}$ of milk was mixed with $45 \mathrm{~mL}$ of $2 \%$ tri-sodium citrate (Honeywell, Charlotte, NC, USA). After centrifuge at $16,000 \times g$ for 5 min at $4{ }^{\circ} \mathrm{C}$, the top fat layer was removed using sterile cotton swabs and the supernatant was discarded. Microbial DNA extraction was performed using DNeasy ${ }^{\circledR}$ PowerFood ${ }^{\circledR}$ Microbial Kit (MoBio Laboratories Inc., Carlsbad, CA, USA) according to the manufacturer's instructions. The extracted DNA was stored at $-20^{\circ} \mathrm{C}$ until processing.

\subsection{Quantification of Total DNA}

The total DNA isolated from the milk samples was quantified fluorometrically with a Qubit 4.0 fluorometer (Invitrogen, Carlsbad, CA, USA) using Qubit dsDNA HS Assay Kit (Invitrogen). The purity of the DNA was evaluated by measuring the ratio of absorbance in A260/280 and A260/230 nm using a spectrophotometer (NanoDrop Thermo Scientific, USA).

\subsection{Barcoded Illumina MiSeq Amplicon Sequencing of Bacterial 16s rRNA Gene}

The 16S rRNA bacterial gene was amplified using primers V3: 5'-TCGTCGGCAGCGTCA GATGTGTATAAGAGACAG-3' and V4: 5'-GTCTCGTGGGCTCGGAGATGTGTATAAGAGACAG-3' . Amplicons were paired-end $(2 \times 150 \mathrm{nt})$ sequenced according to the protocol provided by Illumina (https:/support.illumina.com/documents/documentation/chemistry_documentation/16s/ 16s-metagenomic-library-prep-guide-15044223-b.pdf), and as described by Kamilari et al. [3]. The sequencing runs were performed using a MiSeq 300 cycle Reagent Kit v2 (Illumina, USA) (5\% PhiX), on a MiSeq Illumina sequencing platform (Illumina, San Diego, CA, USA).

\subsection{Microbiome and Statistical Analysis}

The analysis of the FASTQ sequences was performed using Qiime 2 version 2020.2 [20]. For raw sequences quality filtering, the Phred33 quality threshold was used. Trimmomatic was applied for the removal of adapter sequences, FASTQ trimming and reads quality control [21]. Further, the DADA2 algorithm [22] completed the correction of errors of Illumina-sequenced amplicons, removing low-quality reads and reads that exceeded 2 expected errors, including chimeric sequences. Sequences alignment was performed via Mafft (via q2-alignment) [23]. Alpha diversity metrics (Shannon, Simpson and Chao1), rarefaction analysis and beta diversity index (Bray-Curtis similarity) were estimated via Qiime2 (version 2020.2). Principle coordinate analysis (PCoA) was applied to find similarities among samples using q2-diversity after the eight milk samples were rarefied (subsampled without replacement) to 3531 sequences per sample. The alpha rarefaction curve was plotted with 25 sampling depths. The clustering of the $16 \mathrm{~S}$ rDNA sequences and the filtering in operational taxonomic units (OTUs) was performed using the 16s Metagenomics App from BaseSpace against the Illumina-curated version of GreenGenes (v.05.2013) [24,25]. The classified OTUs were defined at $\geq 97 \%$ of sequence homology and converted to percentages (relative abundances), to determine the representation of each microbe among treatments. OTUs with relative abundance lower than $0.001 \%$ were excluded.

All raw sequence data in read pairs format were deposited to the National Centre for Biotechnology Information (NCBI) in the Sequence Read Archive (SRA) under BioProject PRJNA624962.

\section{Results}

The present study was performed to investigate the microbial diversity shaping and the impact of storage conditions on the bacterial communities' composition of fresh raw goat milk, using the HTS approach. 


\subsection{Abundance and Diversity of Members of the Bacterial Microbiota}

Eight examined sample sets were used as input to the Illumina MiSeq to generate 131,992 high-quality sequencing reads, with an average of 16,499 sequencing reads per sample (range $=8047-30,359$, STD $=7639.94)($ Table 2). High-quality sequences were grouped into an average number of 156.25 OTUs (range $=20-824, S D=275.58$ ). Alpha diversity indices, including Shannon, Simpson and Chao estimator, are also shown in Table 2. Significantly higher Shannon and Simpson diversity indices were indicated in milk samples stored immediately after milking at $-80^{\circ} \mathrm{C}$, compared to samples that were kept $\mathrm{O} / \mathrm{N}$ at $4{ }^{\circ} \mathrm{C}(p=0.02$ for both indices), based on the Kruskal-Wallis test (Figure 1, Figure S1, respectively).

Table 2. Sample information, microbial diversity and sequence abundance.

\begin{tabular}{ccccccc}
\hline Sample-ID & Filtered Reads & Raw Reads & Shannon & Simpson & Chao1 & Observed OTUs \\
\hline G1 & 15,744 & 29,480 & 3.454846 & 0.892831 & 23 & 20 \\
G1S & 30,359 & 59,132 & 2.944104 & 0.829086 & 62 & 42 \\
G2 & 8047 & 14,181 & 4.108257 & 0.922543 & 35 & 35 \\
G2S & 8293 & 16,347 & 3.117575 & 0.848981 & 33 & 33 \\
G3 & 14,755 & 38,065 & 8.598082 & 0.995163 & 1111 & 824 \\
G3S & 24,740 & 54,450 & 2.756315 & 0.801392 & 75 & 44 \\
G4 & 15,988 & 37,402 & 5.707971 & 0.956729 & 219 & 196 \\
G4S & 14,066 & 28,321 & 2.811905 & 0.811581 & 75 & 56 \\
\hline
\end{tabular}

Samples names that contain the letter $\mathrm{S}$ at the end are those that were kept $\mathrm{O} / \mathrm{N}$ at $4{ }^{\circ} \mathrm{C}$, whereas samples names without the ending $\mathrm{S}$ are those that were stored immediately after milking at $-80^{\circ} \mathrm{C}$.

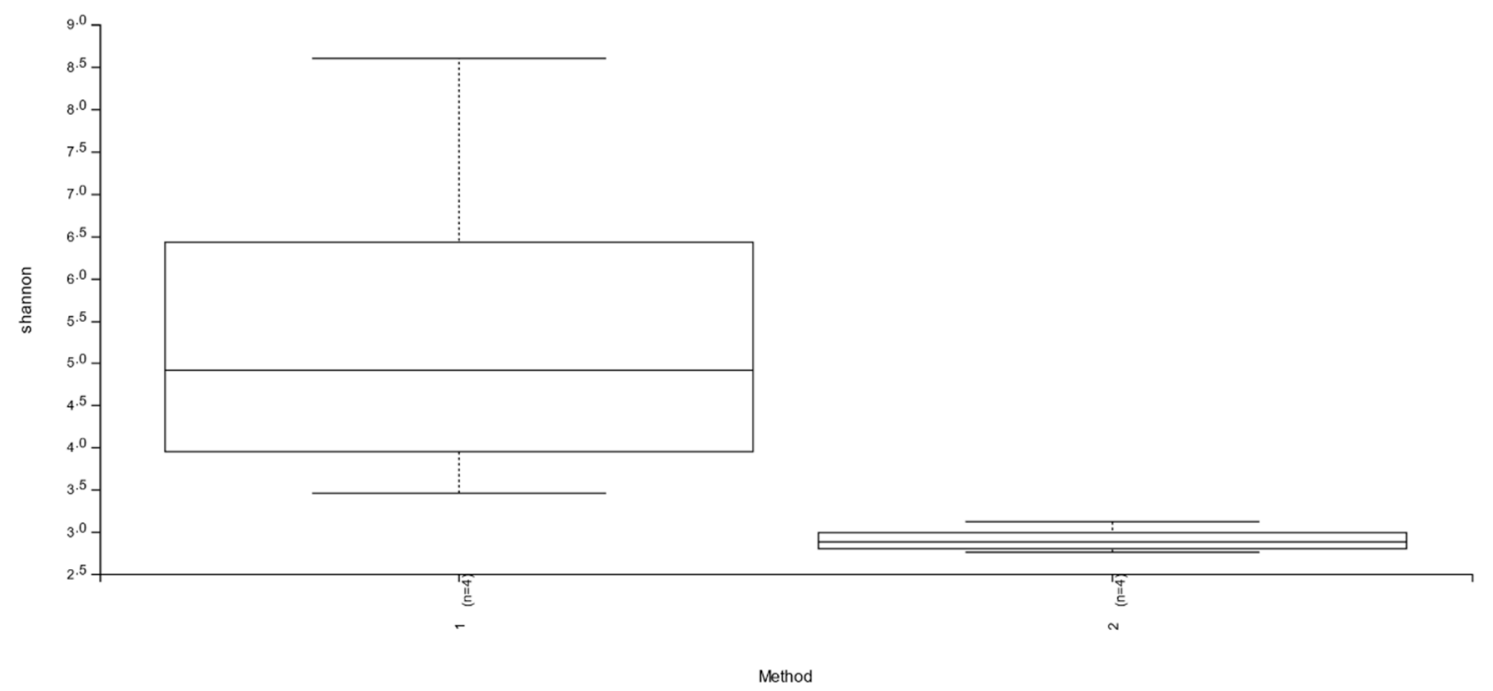

Figure 1. Boxplots showing alpha diversity analysis metrics with Shannon difference between milk samples that were immediately stored after milking at $-80{ }^{\circ} \mathrm{C}(1)$ and that were kept $\mathrm{O} / \mathrm{N}$ at $4{ }^{\circ} \mathrm{C}(2)$ $(p=0.02)$, based on the Kruskal-Wallis test.

\subsection{Taxonomic Composition of Bacterial Communities in Goat and Sheep Milk Samples}

OTU clustering revealed the dominant presence of the bacterial phyla Proteobacteria and Firmicutes. Bacteroidetes and Actinobacteria were detected in lower relative abundances. Reads corresponding to additional Phyla, such as Cyanobacteria, Verrucomicrobia, Tenericutes, Chloroflexi and Nitrospirae, were also found. At the genus level, immediately stored at $-80{ }^{\circ} \mathrm{C}$ milk samples were mostly characterized by the presence of the Gram-negative bacteria Acinetobacter and Pseudomonas (Figure 2B). Moreover, reads corresponding to the genera Corynebacterium, Chryseobacterium, Bacteroides, Methylobacterium and Clostridium were detected in some samples. Furthermore, increased relative abundance of the genus Enhydrobacter was detected in sample G4 and of the genera Lactobacillus, 
Kocuria, Sphingomonas and Chitinophaga in sample S1. In milk samples that were kept $\mathrm{O} / \mathrm{N}$ at $4{ }^{\circ} \mathrm{C}$, the bacterial diversity was most consistent and characterized by the dominant presence of the Gram-negative, aerobic Phyllobacterium.

A

\section{Bacterial Families Relative Abundance}
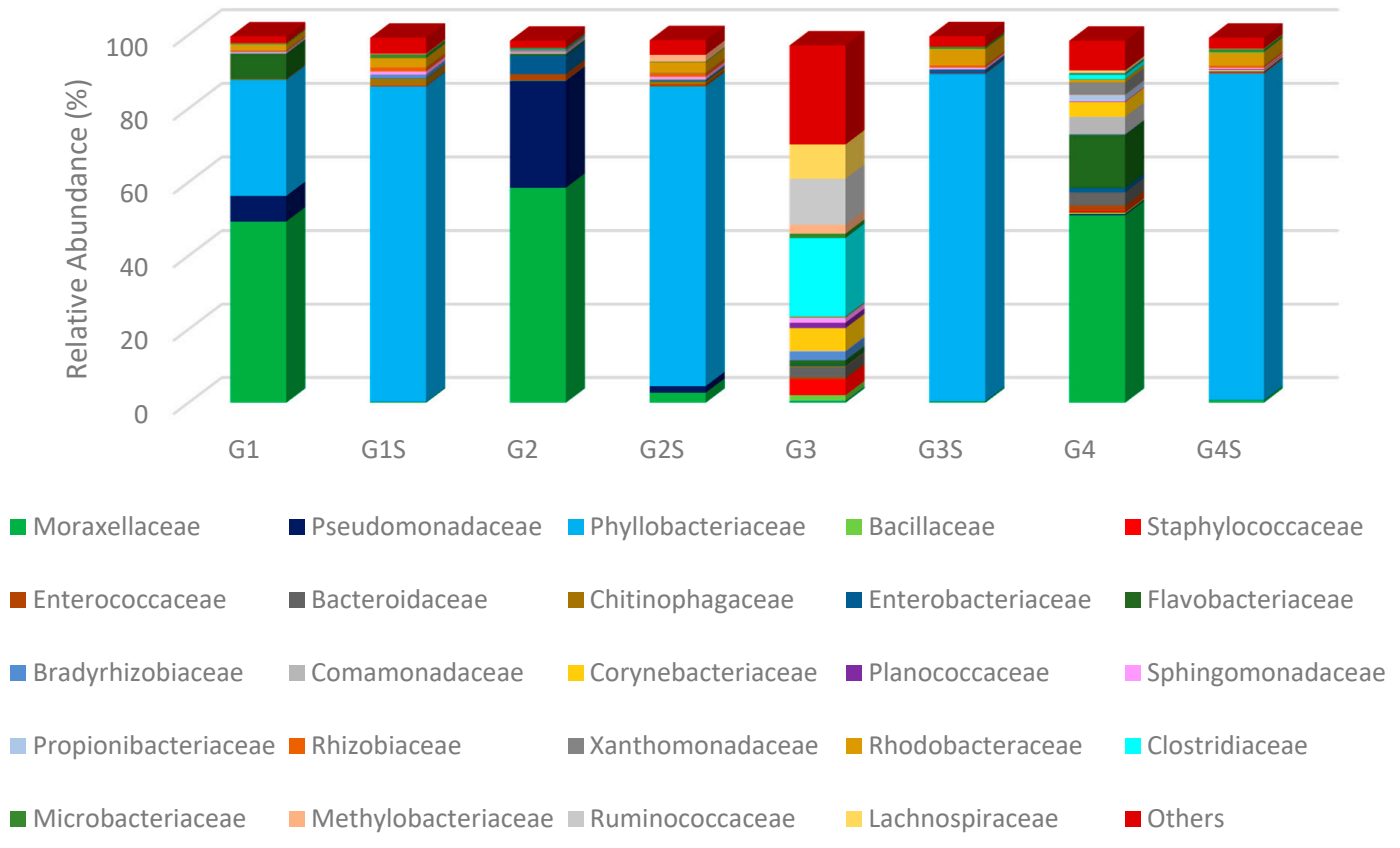

$\underline{\mathrm{B}}$

\section{Bacterial Genera Relative Abundance}

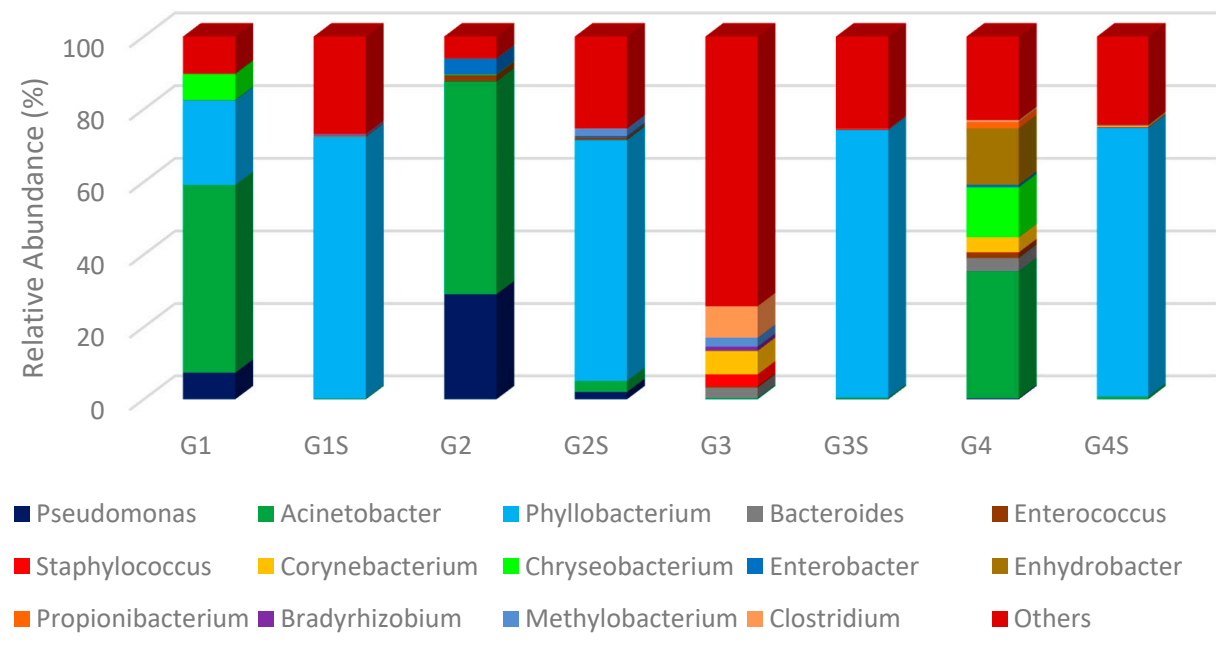

Figure 2. 3D 100\% stacked column chart of the relative abundance of the major taxonomic groups detected by high-throughput sequencing (HTS) at: (A) family level and (B) genus level, for four immediately stored at $-80{ }^{\circ} \mathrm{C}$ goat milk samples and the same for four that were kept $\mathrm{O} / \mathrm{N}$ at $4{ }^{\circ} \mathrm{C}$ (G1S, G2S, G3S and G4S). Only taxa with relative representation $>1 \%$ in at least one sample are shown. 


\subsection{Relationships Between Milk Samples Bacterial Communities}

To evaluate differences in the bacterial community compositions between the two different storage conditions, Bray-Curtis similarity index-based microbiota structure analysis was performed. The analysis indicated increased similarity among the bacterial communities of milk samples that were stored at $4{ }^{\circ} \mathrm{C}$ overnight, and a clear separation with all but one sample (Figure 3). The principal coordinates 1, 2 and 3 explained $51.64 \%, 22.12 \%$ and $19.58 \%$ of the variation, respectively.

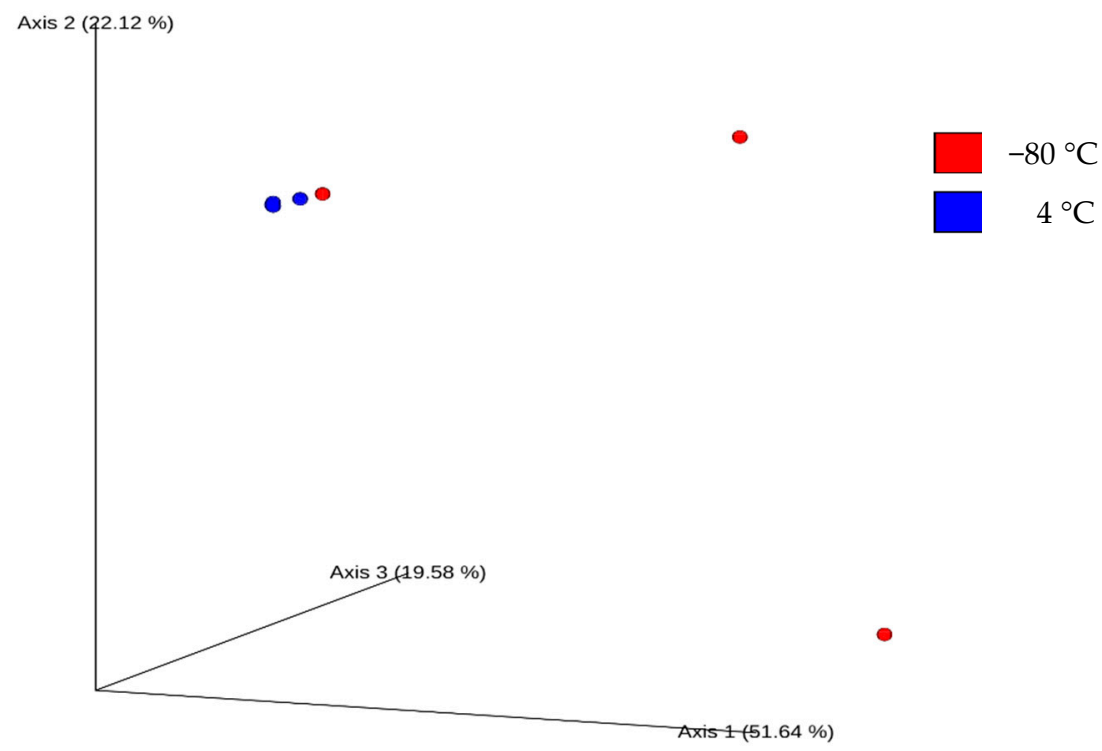

Figure 3. PCoA analysis of milk samples. PCoA plots of Bray-Curtis distance, showing milk samples stored at $-80^{\circ} \mathrm{C}$ (red dots) or at $4{ }^{\circ} \mathrm{C}$ (blue dots). Clustering of points means similarity in relative abundances of operational taxonomic units (OTUs) among those samples.

\section{Discussion}

The directly applied after milking storage conditions are critical for raw milk and raw milk cheeses' microbial communities shaping [12,26]. The present study was performed to provide a snapshot of the bacterial communities detected in raw goat milk (a) after milking and (b) after being kept O/N at $4{ }^{\circ} \mathrm{C}$, using high-throughput sequencing (HTS). To the best of our knowledge, this is the first study performed to compare the bacterial diversity of goat milk under the two different storage conditions.

The composition of milk and milk products microbiota varies based on the animal's diet, breed, species, season, feeding managements, geographic areas, environmental conditions, etc. [26,27]. The present study provides an indication of the existence of differences in the microbiome between the different goat milk farms. Noteworthy, milk samples were collected from different geographic areas of Cyprus, and the animals had different diets. OTU analysis of the $16 \mathrm{~S}$ rRNA gene sequences revealed that in raw goat milk stored directly at $-80^{\circ}$, an increased number of reads corresponding to the Gram-negative genera Acinetobacter and Pseudomonas was detected. Reads corresponding to the genera Chryseobacterium, Corynebacterium, Methylobacterium, Enhydrobacter, Bacteroides and Clostridium were additionally found. A previous 16S rRNA gene metagenomic study in China also reported increased relative representation of spoilage Acinetobacter and Pseudomonas in goat milk (Table 3) [16]. In contrast to the present study, Zhang et al. indicated the predominant presence of the Gram-negative Enterobacter, several strains of which are pathogenic. The genus Pseudomonas was also detected in high percentages in other HTS reports on the goat microbiome [4,14,15]. Pseudomonas spp. produce extracellular enzymes able to effectively digest milk proteins and fats, providing them with the advantage to grow in raw milk [28]. The secretion of proteolytic enzymes by Pseudomonas spp. is considered one of the major causes of milk spoilage during storage at low temperatures [29]. Acinetobacter spp., which are also associated with milk spoilage, are ubiquitous in nature and able to adapt and survive in several 
environmental conditions [30]. Notably, the G3 sample was distinguished from the other samples at the family level due to the increased relative representation of members of the families Clostridiaceae, Ruminococaceae and Lachnospiraceae. These families contain species able to produce short-chain fatty acids (SCFA), such as butyrate and acetate, that offer a beneficial contribution to human and animal health $[31,32]$.

Table 3. The relative abundance of bacterial genera in goat milk based on 16S rRNA gene metagenomic studies.

\begin{tabular}{|c|c|c|c|c|c|}
\hline \multirow{2}{*}{ Type of Milk } & \multirow{2}{*}{ Country } & \multicolumn{3}{|c|}{ Relative Abundance } & \multirow{2}{*}{ Reference } \\
\hline & & $\geq 25 \%$ & $10-24 \%$ & $1-9 \%$ & \\
\hline $\begin{array}{c}\text { Goat } \\
\text { Macheras } \\
(n=12)\end{array}$ & $\begin{array}{l}\text { Limassol/ } \\
\text { Cyprus }\end{array}$ & Acinetobacter & $\begin{array}{l}\text { Pseudomonas, } \\
\text { Phyllobacterium }\end{array}$ & Chryseobacterium & \multirow{4}{*}{ Present study } \\
\hline $\begin{array}{c}\text { Goat } \\
\text { Macheras } \\
(\mathrm{n}=30)\end{array}$ & $\begin{array}{l}\text { Paphos/ } \\
\text { Cyprus }\end{array}$ & $\begin{array}{l}\text { Acinetobacter, } \\
\text { Pseudomonas }\end{array}$ & - & - & \\
\hline $\begin{array}{c}\text { Goat } \\
\text { Alpine } \\
(n=3)\end{array}$ & $\begin{array}{l}\text { Nicosia/ } \\
\text { Cyprus }\end{array}$ & - & - & $\begin{array}{l}\text { Bacteroides, } \\
\text { Staphylococcus, } \\
\text { Corynebacterium, } \\
\text { Methylobacterium, } \\
\text { Clostridium }\end{array}$ & \\
\hline $\begin{array}{c}\text { Goat } \\
\text { Damascus } \\
(\mathrm{n}=26)\end{array}$ & Limassol/Cyprus & Acinetobacter & $\begin{array}{l}\text { Chryseobacterium, } \\
\text { Enhydrobacter }\end{array}$ & $\begin{array}{c}\text { Bacteroides, } \\
\text { Corynebacterium }\end{array}$ & \\
\hline $\begin{array}{c}\text { Goat } \\
\text { Macheras } \\
(n=10)\end{array}$ & Paphos/Cyprus & $\begin{array}{l}\text { Lactococcus, } \\
\text { Leuconostoc }\end{array}$ & Pseudomonas & $\begin{array}{l}\text { Carnobacterium } \\
\text { Pahnella }\end{array}$ & [4] \\
\hline $\begin{array}{c}\text { Goat } \\
\text { Guanzhong } \\
(n=200)\end{array}$ & $\begin{array}{c}\text { Guangxi } \\
\text { Zhuang/China }\end{array}$ & Kluyvera & & $\begin{array}{c}\text { Geobacillus, } \\
\text { Thermus, } \\
\text { Pseudomonas, } \\
\text { Acinetobacter, } \\
\text { Shigella, } \\
\text { Aquabacterium, } \\
\text { Burkholderia, } \\
\text { Streptococcus }\end{array}$ & [14] \\
\hline $\begin{array}{c}\text { Goat } \\
\text { Alpine, } \\
\text { Toggenburg, } \\
\text { Saanen, } \\
\text { LaMancha } \\
(n=8)\end{array}$ & United States & Pseudomonas & Rhodococcus & $\begin{array}{l}\text { Micrococcus, } \\
\text { Stenotrophomonas, } \\
\text { Phyllobacterium, } \\
\text { Streptococcus, } \\
\text { Agrobacterium }\end{array}$ & [15] \\
\hline $\begin{array}{c}\text { Goat } \\
\text { Saanen } \\
(n=3)\end{array}$ & \multirow[t]{2}{*}{ China } & Enterobacter & - & $\begin{array}{c}\text { Pseudomonas, } \\
\text { Acinetobacter } \\
\text { Staphylococcus, } \\
\text { Massilia, } \\
\text { Bacillus, } \\
\text { Streptococcus, } \\
\text { Bacteroides }\end{array}$ & \multirow[t]{2}{*}{ [16] } \\
\hline $\begin{array}{c}\text { Goat } \\
\text { Guanzhong } \\
(n=3)\end{array}$ & & - & $\begin{array}{l}\text { Pseudomonas, } \\
\text { Acinetobacter, } \\
\text { Enterobacter }\end{array}$ & $\begin{array}{l}\text { Staphylococcus, } \\
\text { Stenotrophomonas, } \\
\text { Massilia, } \\
\text { Bacillus, } \\
\text { Streptococcus }\end{array}$ & \\
\hline
\end{tabular}


Storage of milk samples $\mathrm{O} / \mathrm{N}$ at $4{ }^{\circ} \mathrm{C}$ contributed to alterations in the milk microbiota, regardless of the animal breed. Initially, the storage conditions led to a reduction in the bacterial diversity, in accordance with other reports [33,34]. This reduction contributed to the Gram-negative, aerobic Phyllobacterium dominance in all samples. These bacteria have been identified in several different environments, but their presence was mostly described in plant tissues, including leaf or root nodules [35-37]. Some strains were found to contain plant growth-promoting potential [38-40]. Previous studies have described Phyllobacterium presence in cow milk [34,41]. However, no other study has ever shown their dominance after keeping the milk in the refrigerator. On the contrary, application of 16S rRNA gene sequencing, Biolog, MALDI-TOF MS, API and Microbact identified the predominance of Pseudomonas and in lower abundances of Acinetobacter, Bacillus, Stenotrophomonas, Hafnia, Burkholderia, Rahnella, Kluyvera, Serratia and Sporosarcina in raw cow milk after storage at $4{ }^{\circ} \mathrm{C}$ for ten days [42]. The prevalence of Pseudomonas (93\% relative abundance) was also indicated after three days of storage at $4{ }^{\circ} \mathrm{C}$ of raw donkey milk, using high-throughput sequencing [33]. Moreover, DGGE and cloning analysis indicated that after $24 \mathrm{~h}$ of cold incubation, the milk microbiota was dominated by Streptococcus, Staphylococcus and Bacillus, whereas after $48 \mathrm{~h}$, was by Pseudomonas and Acinetobacter [34]. This study identified the presence of Phyllobacterium after $24 \mathrm{~h}$ of storage but in low relative abundances. Furthermore, in contrast to the present and the aforementioned studies, Doyle et al. [43] indicated that neither the temperature nor the duration of storage had a notable effect on the raw cow milk microbiota after $96 \mathrm{~h}$ of storage. In agreement with Doyle et al. [43], Porcellato et al. [44] revealed the lack of significant changes in the bacterial composition of bovine milk after storage at $4{ }^{\circ} \mathrm{C}$, throughout the milk's shelf life.

Furthermore, by applying the $16 \mathrm{~S}$ rRNA sequencing methodology, no food-borne diseases-causing bacteria, such as Listeria monocytogenes, Staphylococcus aureus, Salmonella spp. and pathogenic Escherichia coli [31,45], were detected in any of the samples tested. Previous HTS studies in milk and dairy products have revealed the presence of some of these pathogens [46,47]. However, no culture-based techniques or molecular techniques, such as polymerase chain reaction (PCR), multiplex PCR, real-time quantitative PCR (qPCR) and whole-genome sequencing, were used in the present study to confirm the absence of these pathogens in the milk samples.

\section{Conclusions}

The present study provided an indication that keeping the goat milk overnight in the refrigerator after milking may lead to a reduction in the bacterial diversity, as well as in alterations in the bacterial communities' composition. The consequent development of aerobic and psychrotrophic bacteria may spoil the quality of milk and milk products. In the future, milk samples from different animals, including cow, milk and goat, as well as from different breeds, are to be analyzed to provide a better understanding of the microbial communities' composition in raw milk. Factors associated with milk microbiota configuration, such as the origin of milk, the environmental conditions, the feeding management and seasoning, as well as animals' diet and genetics, will also be considered, in addition to the effects of cold storage. Furthermore, the effect of longer than 16-h storage in the refrigerator, as well as of pasteurization, on the bacterial diversity is to be analyzed, to evaluate whether the relative representation of pathogens and spoilage will increase. Further analysis will shed more light on the technological and functional properties of the goat milk microbiome.

Supplementary Materials: Supplementary materials can be found at http://www.mdpi.com/2311-5637/6/4/100/s1.

Author Contributions: Conceptualization, D.T. and P.P.; methodology, E.K., D.A.A., M.E. and S.T.; formal analysis, E.K.; investigation, E.K.; resources, D.T., P.P.; data curation, E.K.; writing-original draft preparation, E.K.; writing-review and editing, D.T. and P.P.; supervision, D.T. and P.P.; project administration, D.T.; funding acquisition, D.T. All authors have read and agreed to the published version of the manuscript.

Funding: This research was funded by INTERREG Greece-Cyprus 2014-2020 Program, Project AGRO-ID, which is co-funded by the European Union (ERDF) and National Resources of Greece and Cyprus. 
Acknowledgments: The authors acknowledge the funding from the project AGRO-ID, INTERREG Greece-Cyprus 2014-2020.

Conflicts of Interest: The authors declare no conflict of interest.

\section{References}

1. Lad, S.S.; Aparnathi, K.D.; Mehta, B.; Velpula, S. Goat Milk in Human Nutrition and Health-A Review. Int. J. Curr. Microbiol. Appl. Sci. 2017, 6, 1781-1792. [CrossRef]

2. Park, Y.W.; Juárez, M.; Ramos, M.; Haenlein, G.F.W. Physico-chemical characteristics of goat and sheep milk. Small Rumin. Res. 2007, 68, 88-113. [CrossRef]

3. Kamilari, E.; Anagnostopoulos, D.A.; Papademas, P.; Kamilaris, A.; Tsaltas, D. Characterizing Halloumi cheese's bacterial communities through metagenomic analysis. LWT 2020, 126, 109298. [CrossRef]

4. Papademas, P.; Aspri, M.; Mariou, M.; Dowd, S.E.; Kazou, M.; Tsakalidou, E. Conventional and omics approaches shed light on Halitzia cheese, a long-forgotten white-brined cheese from Cyprus. Int. Dairy J. 2019, 98, 72-83. [CrossRef]

5. Park, Y.W. Goat Milk: Goat Milk-Chemistry and Nutrition. In Handbook of Milk of Non-Bovine Mammals; Park, Y.W., Haenlein, G.F.W., Eds.; Blackwell Publishing Professional: Oxford, UK; Ames, IA, USA, 2006; pp. 34-58.

6. Tagliazucchi, D.; Martini, S.; Shamsia, S.; Helal, A.; Conte, A. Biological activities and peptidomic profile of in vitro-digested cow, camel, goat and sheep milk. Int. Dairy J. 2018, 81, 19-27. [CrossRef]

7. Capriotti, A.L.; Cavaliere, C.; Piovesana, S.; Samperi, R.; Laganà, A. Recent trends in the analysis of bioactive peptides in milk and dairy products. Anal. Bioanal. Chem. 2016, 408, 2677-2685. [CrossRef]

8. Marcone, S.; Belton, O.; Fitzgerald, D.J. Milk-derived bioactive peptides and their health promoting effects: A potential role in atherosclerosis. Br. J. Clin. Pharmacol. 2017, 83, 152-162. [CrossRef]

9. Nielsen, S.D.; Beverly, R.L.; Qu, Y.; Dallas, D.C. Milk bioactive peptide database: A comprehensive database of milk protein-derived bioactive peptides and novel visualization. Food Chem. 2017, 232, 673-682. [CrossRef]

10. Griffiths, M.I.W.; Laing, R.R.; Roy, D.; Mafu, A.A. Psychrotrophs in dairy products: Their effects and their control. Crit. Rev. Food Sci. Nutr. 1994, 34, 1-30. [CrossRef]

11. Hantsis-Zacharov, E.; Halpern, M. Culturable psychrotrophic bacterial communities in raw milk and their proteolytic and lipolytic traits. Appl. Environ. Microbiol. 2007, 73, 7162-7168. [CrossRef]

12. Alessandria, V.; Ferrocino, I.; De Filippis, F.; Fontana, M.; Rantsiou, K.; Ercolini, D.; Cocolin, L. Microbiota of an Italian Grana-like cheese during manufacture and ripening, unraveled by $16 \mathrm{~S}$ rRNA-based approaches. Appl. Environ. Microbiol. 2016, 82, 3988-3995. [CrossRef]

13. Quigley, L.; O'Sullivan, O.; Stanton, C.; Beresford, T.P.; Ross, R.P.; Fitzgerald, G.F.; Cotter, P.D. The complex microbiota of raw milk. FEMS Microbiol. Rev. 2013, 37, 664-698. [CrossRef] [PubMed]

14. Huang, F.; Liu, S.; Zhou, X.; Wang, P.; He, R.; Zhou, Z.; Zou, C. High-throughput sequencing analysis of bacterial diversity in raw and pasteurized goat milk. BioRxiv 2019, 751149. [CrossRef]

15. McInnis, E.A.; Kalanetra, K.M.; Mills, D.A.; Maga, E.A. Analysis of raw goat milk microbiota: Impact of stage of lactation and lysozyme on microbial diversity. Food Microbiol. 2015, 46, 121-131. [CrossRef] [PubMed]

16. Zhang, F.; Wang, Z.; Lei, F.; Wang, B.; Jiang, S.; Peng, Q.; Zhang, J.; Shao, Y. Bacterial diversity in goat milk from the Guanzhong area of China. J. Dairy Sci. 2017, 100, 7812-7824. [CrossRef]

17. Di Bella, J.M.; Bao, Y.; Gloor, G.B.; Burton, J.P.; Reid, G. High throughput sequencing methods and analysis for microbiome research. J. Microbiol. Methods 2013, 95, 401-414. [CrossRef]

18. De Filippis, F.; Parente, E.; Ercolini, D. Metagenomics insights into food fermentations. Microb. Biotechnol. 2017, 10, 91-102. [CrossRef]

19. Loman, N.J.; Constantinidou, C.; Chan, J.Z.M.; Halachev, M.; Sergeant, M.; Penn, C.W.; Robinson, E.R.; Pallen, M.J. High-throughput bacterial genome sequencing: An embarrassment of choice, a world of opportunity. Nat. Rev. Microbiol. 2012, 10, 599-606. [CrossRef] [PubMed]

20. Bolyen, E.; Rideout, J.R.; Dillon, M.R.; Bokulich, N.A.; Abnet, C.C.; Al-Ghalith, G.A.; Alexander, H.; Alm, E.J.; Arumugam, M.; Asnicar, F.; et al. Reproducible, interactive, scalable and extensible microbiome data science using QIIME 2. Nat. Biotechnol. 2019, 37, 852-857. [CrossRef]

21. Bolger, A.M.; Lohse, M. Usadel, BTrimmomatic: A flexible trimmer for Illumina Sequence Data. Bioinformatics 2014, btu170. [CrossRef] 
22. Callahan, B.J.; McMurdie, P.J.; Rosen, M.J.; Han, A.W.; Johnson, A.J.; Holmes, S.P. DADA2: High-resolution sample inference from Illumina amplicon data. Nat Methods 2016, 13, 581-583. [CrossRef] [PubMed]

23. Katoh, K.; Standley, D.M. MAFFT Multiple Sequence Alignment Software Version 7: Improvements in Performance and Usability. Mol. Biol. Evol. 2013, 30, 772-780. [CrossRef] [PubMed]

24. DeSantis, T.Z.; Hugenholtz, P.; Larsen, N.; Rojas, M.; Brodie, E.L.; Keller, K.; Huber, T.; Dalevi, D.; Hu, P.; Andersen, G.L. Greengenes, a chimera-checked $16 \mathrm{~S}$ rRNA gene database and workbench compatible with ARB. Appl. Environ. Microbiol. 2006, 72, 5069-5072. [CrossRef] [PubMed]

25. Macklin, M.T.; Mann, H.B. Fallacies inherent in the proband method of analysis of human pedigrees. Am. J. Dis. Child. 1947, 74, 456-467. [CrossRef]

26. Kamilari, E.; Tomazou, M.; Antoniades, A.; Tsaltas, D. High throughput sequencing technologies as a new toolbox for deep analysis, characterization and potentially authentication of protection designation of origin cheeses? Int. J. Food Sci. 2019, 2019, 5837301. [CrossRef]

27. Oikonomou, G.; Addis, M.F.; Chassard, C.; Nader-Macias, M.E.F.; Grant, I.; Delbès, C.; Bogni, C.I.; Le Loir, Y.; Even, S. Milk Microbiota: What Are We Exactly Talking About? Front. Microbiol. 2020, 11, 60. [CrossRef]

28. Quigley, L.; McCarthy, R.; O'Sullivan, O.; Beresford, T.P.; Fitzgerald, G.F.; Ross, R.P.; Stanton, C.; Cotter, P.D. The microbial content of raw and pasteurized cow milk as determined by molecular approaches. J. Dairy Sci. 2013, 96, 4928-4937. [CrossRef] [PubMed]

29. Meng, L.; Zhang, Y.; Liu, H.; Zhao, S.; Wang, J.; Zheng, N. Characterization of Pseudomonas spp. and associated proteolytic properties in raw milk stored at low temperatures. Front. Microbiol. 2017, 8, 2158. [CrossRef]

30. Gurung, M.; Nam, H.M.; Tamang, M.D.; Chae, M.H.; Jang, G.C.; Jung, S.C.; Lim, S.K. Prevalence and antimicrobial susceptibility of Acinetobacter from raw bulk tank milk in Korea. J. Dairy Sci. 2013, 96, 1997-2002. [CrossRef]

31. Esquivel-Elizondo, S.; Ilhan, Z.E.; Garcia-Pena, E.I.; Krajmalnik-Brown, R. Insights into butyrate production in a controlled fermentation system via gene predictions. mSystems 2017, 2, 13. [CrossRef]

32. Den Besten, G.; Van Eunen, K.; Groen, A.K.; Venema, K.; Reijngoud, D.J.; Bakker, B.M. The role of short-chain fatty acids in the interplay between diet, gut microbiota and host energy metabolism. J. Lipid Res. 2013, 54, 2325-2340. [CrossRef] [PubMed]

33. Russo, P.; Fiocco, D.; Albenzio, M.; Spano, G.; Capozzi, V. Microbial Populations of Fresh and Cold Stored Donkey Milk by High-Throughput Sequencing Provide Indication for A Correct Management of This High-Value Product. Appl. Sci. 2020, 10, 2314. [CrossRef]

34. Raats, D.; Offek, M.; Minz, D.; Halpern, M. Molecular analysis of bacterial communities in raw cow milk and the impact of refrigeration on its structure and dynamics. Food Microbiol. 2011, 28, 465-471. [CrossRef]

35. Mantelin, S.; Fischer-Le Saux, M.; Zakhia, F.; Béna, G.; Bonneau, S.; Jeder, H.; de Lajudie, P.; Cleyet-Marel, J.C. Emended description of the genus Phyllobacterium and description of four novel species associated with plant roots: Phyllobacterium bourgognense sp. nov., Phyllobacterium ifriqiyense sp. nov., Phyllobacterium leguminum sp. nov. and Phyllobacterium brassic. Int. J. Syst. Evol. Microbiol. 2006, 56, 827-839. [CrossRef]

36. Lambert, B.; Joos, H.; Dierickx, S.; Vantomme, R.; Swings, J.; Kersters, K.; Van Montagu, M. Identification and plant interaction of a Phyllobacterium sp., a predominant rhizobacterium of young sugar beet plants. Appl. Environ. Microbiol. 1990, 56, 1093-1102. [CrossRef]

37. Mergaert, J.; Cnockaert, M.C.; Swings, J. Phyllobacterium myrsinacearum (subjective synonym Phyllobacterium rubiacearum) emend. Int. J. Syst. Evol. Microbiol. 2002, 52, 1821-1823. [CrossRef]

38. Bertrand, H.; Nalin, R.; Bally, R.; Cleyet-Marel, J.C. Isolation and identification of the most efficient plant growth-promoting bacteria associated with canola (Brassica napus). Biol. Fertil. Soils 2001, 33, 152-156. [CrossRef]

39. Larcher, M.; Muller, B.; Mantelin, S.; Rapior, S.; Cleyet-Marel, J.C. Early modifications of Brassica napus root system architecture induced by a plant growth-promoting Phyllobacterium strain. New Phytol. 2003, 160, 119-125. [CrossRef]

40. Mantelin, S.; Desbrosses, G.; Larcher, M.; Tranbarger, T.J.; Cleyet-Marel, J.C.; Touraine, B. Nitrate-dependent control of root architecture and $\mathrm{N}$ nutrition are altered by a plant growth-promoting Phyllobacterium sp. Planta 2006, 223, 591-603. [CrossRef] 
41. Teh, G.K.; Flint, S.; Brooks, J.; Knight, G. Raw milk quality influenced by biofilms and the effect of biofilm growth on dairy product quality. In Biofilms in the Dairy Industry; Teh, K.H., Flint, S., Brooks, J., Knight, G., Eds.; Wiley: Chichester, UK, 2015; pp. 65-98. [CrossRef]

42. Vithanage, N.R.; Yeager, T.R.; Jadhav, S.R.; Palombo, E.A.; Datta, N. Comparison of identification systems for psychrotrophic bacteria isolated from raw bovine milk. Int. J. Food Microbiol. 2014, 189, 26-38. [CrossRef]

43. Doyle, C.J.; Gleeson, D.; O’Toole, P.W.; Cotter, P.D. High-throughput metataxonomic characterization of the raw milk microbiota identifies changes reflecting lactation stage and storage conditions. Int. J. Food Microbiol. 2017, 255, 1-6. [CrossRef] [PubMed]

44. Porcellato, D.; Aspholm, M.; Skeie, S.B.; Monshaugen, M.; Brendehaug, J.; Mellegård, H. Microbial diversity of consumption milk during processing and storage. Int. J. Food Microbiol. 2018, 266, 21-30. [CrossRef] [PubMed]

45. Cancino-Padilla, N.; Fellenberg, M.A.; Franco, W.; Ibáñez, R.A.; Vargas-Bello-Pérez, E. Foodborne bacteria in dairy products: Detection by molecular techniques. Cienc. Investig. Agrar. 2017, 44, 215-229. [CrossRef]

46. De Filippis, F.; La Storia, A.; Stellato, G.; Gatti, M.; Ercolini, D. A selected core microbiome drives the early stages of three popular Italian cheese manufactures. PLoS ONE 2014, 9, e89680. [CrossRef] [PubMed]

47. Yeluri Jonnala, B.R.; McSweeney, P.L.H.; Sheehan, J.J.; Cotter, P.D. Sequencing of the Cheese Microbiome and Its Relevance to Industry. Front. Microbiol. 2018, 9, 1020. [CrossRef]

Publisher's Note: MDPI stays neutral with regard to jurisdictional claims in published maps and institutional affiliations. 